\title{
KEHIDUPAN SOSIAL, EKONOMI DAN BUDAYA MASYARAKAT DESA LABUHAN HAJI DALAM HUBUNGANNYA DENGAN ETNIS CINA PASCA G 30 SEPTEMBER 1965-1966
}

\author{
Ahmad Afandi \\ Pendidikan Sejarah, Universitas Muhammadiyah Mataram, afandi190384@gmail.com
}

\section{INFO ARTIKEL}

RiwayatArtikel:

Diterima: 23-1 1-2017

Disetujui: 23-12-2017

\section{Kata Kunci:}

1. Kehidupan Sosial

2. Ekonomi

3. G30 September 1965

\begin{abstract}
ABSTRAK
Tulisan ini menggambarkan tentang terjadinya peristiwa $G 30$ septemberyang sempat mengguncang kehidupan politik Indonesia yang berakibat pula terhadap kehidupan sosial, ekonomi dan budaya masyarakat Indonesia, khususnya di Daerah Nusa Tenggara Barat yaitu Desa Labuhan Haji Kecamatan Labuhan Haji Kabupaten Lombok Timur ikut merasakan dampak dari peristiwa G 30 september tahun 1965. Sebelum terjadinya G 30 September masyarakat Labuhan Haji pernah melakukan hubungan sosial, ekonomi dan budaya dengan Etnis Cina, hubungan tersebut tidak berjalan lama, pada tahun 1965 para pengusaha Cina diusir secara paksa oleh masyarakat Lombok, karena dianggap sebagai antek PKI, hal ini disebabkan karena di Negara Cina berkembang partai Komunis. Karena adanya peristiwa G 30 september tahun 1965 para pengusaha Cina yang ada di Desa Labuhan Haji di curigai sebagai antek PKI dan diusir dari daerah Labuhan Haji yang mengakibatkan terpuruknya kehidupan masyarakat Labuhan Haji dan sekitarnya khususnya masyarakat Desa Labuhan Haji.
\end{abstract}

This paper describes the occurrence of the events of $G 30$ September which had shook the Indonesian political life that also affected the social, economic and cultural life of Indonesian people, especially in West Nusa Tenggara, Labuhan Haji, Labuhan Haji Sub-District, East Lombok Regency, felt the impact of the September 30, 1965 G. events. September Labuhan Haji community once conducted social, economic and cultural relations with the Ethnic Chinese, the relationship did not go long, in 1965 Chinese businessmen were forcibly expelled by Lombok society, because it is considered as PKI's henchman, this is because in the developing Chinese Party Communist. Because of the events of G 30 September 1965 the Chinese businessmen in Labuhan Haji Village were suspected of being PKI's henchmen and expelled from Labuhan Haji area which resulted in the decline of Labuhan Haji and surrounding communities, especially the people of Labuhan Haji Village.

\section{A. LATAR BELAKANG}

Bangsa indonesia yang memiliki semboyan Bhineka Tunggal Ika, tidak kurang memiliki 726 suku bangsa dan memiliki budaya dengan berbagai ragam dan jenis. Budaya-budaya tersebut masing-masing mempunyai nilai-nilai serta kekuatannya sendiri yang dapat disumbangkan kepada terbentuknya kebudayaan nasional. Hal tersebut tentu bisa dilihat lebih jauh bagaimana peranan dari identitas di dalam kehidupan suku-suku bangsa di Indonesia.
Gerry van Klinken (Tilaar, 2007:153) telah meneliti perkembangan kehidupan etnis di Indonesia. Sebagaimana juga yang terjadi di bagian dunia lain, munculnya kelompok-kelompok etnis dapat menyebabkan ketidakstabilan di dalam masyarakat, bahkan sampai pada konflik etnis.

Sejarah lokal adalah sejarah dari suatu "tempat" atau "locality", yang batasanya ditentukan oleh "perjanjian" yang diajukan oleh penulis sejarah (Abdullah, 1990:15). sejarah lokal secara sederhana dapat 
dirumuskan sebagai kisah di kelampauan dari kelompokkelompok masyarakat yang berada pada "daerah geografis" yang terbatas baik yang menyangkut komunitas township, county, maupun village, dan sejenisnya.

Sejarah lokal di Indonesia dalam pengkajiannya baik yang dilakukan oleh sarjana-sarjana barat maupun Indonesia sejak zaman dahulu, ternyata masih relatif sedikit. Kartodirdjo (1993: 74) berpendapat, hal ini disebabakan oleh adanya kesulitan memperoleh sumbersumber yang cukup lengkap sangat dibutuhkan oleh kerena bisanya sejarah lokal berupa sejarah mikro, suatu jenis sejarah yang menuntut metodologis khusus, yaitu yang mempunyai kerangka konseptual cukup halus agar dapat melakukan analisis yang tajam.

Sebagai sebuah daerah yang merupakan bagian dari lokalitas di kawasan pulau Lombok Labuhan Haji merupakan wilayah yang strategis bila dilihat dari letak dan geografisnya. Desa Labuhan Haji merupakan daerah pesisir, jika ditinjau kembali Labuhan Haji merupakan pelabuhan yang sering digunakan oleh para pengusaha Arab dan Cina dalam melakukan aktivitas perdagangan atau kegiatan prekonomian. Aktivitas ekonomi oleh bangsa Cina dan Arab telah banyak memberikan pengaruh positif bagi kehidupan sosial, ekonomi dan budaya masyarakat Desa Labuhan Haji.

Desa Labuhan Haji adalah salah satu desa dari delapan desa yang berada di wilayah administratif Kecamatan Labuhan Haji. Berdasarkan sejarah, daerah ini dinamakan Labuhan Haji karena pada era pendudukan Belanda dan Jepang masyarakat Lombok memanfaatkan pelabuhan ini sebagai tempat awal berangkat menunaikan ibadah haji ke Mekah, Arab Saudi.

Pada tahun 1895, alat transportasi belum secanggih sekarang, dan masih didominasi melalui perairan laut menggunakan kapal layar untuk sampai di tanah suci, calon-calon haji ini berjuang di laut dan setidaknya membutuhkan tiga bulan perjalanan dalam sekali kesempatan pergi haji. Disamping penggunaannya sebagai pelabuhan untuk pergi berhaji, tempat ini berfungsi pula sebagai pintu masuk para pedagang keturunan Cina ke wilayah Lombok. Usaha mereka tergolong sukses karena dominasi ekonomi pengusaha Cina sangat menonjol, yaitu sebagian besar pemilik pabrik penggilingan padi dan minyak kelapa adalah golongan Etnis Cina. Beberapa lokasi kuburan warga keturunan Cina juga dapat ditemukan seperti terlihat pada daerah Penede Gandor, sekitar 500 meter dari pelabuhan.

Pengusaha Cina membangun pabrik-pabrik di Desa Labuhan Haji, dengan adanya pabrik-pabrik ini otomatis memberikan peluang usaha terhadap perekonomian masyarakat Labuhan Haji dan sekitarnya, khususnya masyarakat Labuhan Haji yang sebagian besar berprofesi sebagai nelayan dan ada juga yang sebagai petani ini merupakan budaya yang sudah turun temurun dari nenek moyang sebelumnya, secara otomatis kehidupan masyarakat Desa Labuhan Haji mengalami perubahan dalam bidang prekonomian.

Masyarakat Labuhan Haji menjual hasil penangkapan dan hasil pertaniannya pada pengusaha Cina dan tidak sedikit pula masyarakat yang bekerja sebagai kuli di pabrik-pabrik tertentu. Tidak hanya itu, dengan keberadaan pengusaha Cina ini berarti membuka lowongan kerja di bidang transportasi yaitu bongkar muat barang di pelabuhan Labuhan Haji maupun jalan darat. Dengan demikian selain bekerja sebagai kuli pabrik, dan sebagai produsen barang mentah untuk pabrik pengusaha Cina berarti masyarakat Desa Labuhan Haji Kecamatan Labuhan Haji juga dapat bekerja sebagai kuli bongkar muat barang baik di pelabuhan maupun di darat.

Kegiatan prekonomian yang dilakukan bangsa Cina dan perkembangannya cukup pesat di Desa Labuhan Haji ternyata tidak berlangsung lama. Hal ini disebabkan karena diusirnya para pengusaha Cina oleh bangsa pribumi dari daerah Labuhan Haji, pristiwa inilah yang sampai saat ini disebut oleh masyarakat sebagai pristiwa “Pengganyangan Cina” pada tahun 1965, dimana seluruh harta benda seperti rumah, pabrik barang dagangan dan barang-barang berharga lainnya yang menjadi milik para pengusaha Cina habis dijarah oleh bangsa pribumi. Hal ini disebabkan karena Etnis Cina di Labuhan Haji dianggap sebagai antek PKI. Operasi pengejaran terhadap pimimpinan dan pendukung PKI segera dilakukan. 


\section{B. METODE PENELITIAN}

\section{Jenis dan Pendekatan Penelitian}

Penelitian ini adalah penelitian historis dengan pendekatan kualitatif deskriptif karena penelitian ini diarahkan untuk meneliti, mengkaji dan menjelaskan peristiwa masa lalu melalui metode sejarah yang bersifat kualitatif. Susunan penelitian menggunakan kualitatif yaitu penelitian yang tidak menggunakan statistik dengan ciri khas tersendiri.

Metode penelitian sejarah menggunakan seperangkat aturan dan prinsip sistematis untuk mengumpulkan sumber-sumber sejarah secara efektif, menilainya secara kritik dan mengajukan sintesis dari hasil yang dicapai dalam bentuk tulisan. Adapun metode penelitian sejarah yang digunakan dalam penelitian ini adalah :

a) Heuristik

Menurut G.J Renier mengatakan bahwa "Heuristik adalah suatu teknik, suatu seni dan bukan suatu ilmu. Oleh karena itu, heuristik tidak mempunyai peraturan-peraturan umum. Heuristik sering kali merupakan suatu keterampilan dalam menemukan, menangani, dan merinci bibiliografi, atau mengklasifikasi, dan merawat catatan-catatan". Salah satu prinsip dalam heuristik adalah sejarawan harus mencari sumber primer, sumber primer di dalam penelitian sejarah adalah sumber yang disampaikan oleh saksi mata, dalam hal ini dalam bentuk dokumen, misalnya catatan rapat, daftar anggaran organisasi, dan arsip-arsip laporan penelitian atau organisasi massasedangakan dalam sumber lisan yang dianggap primer adalah wawasan langsung dengan pelaku peristiwa atau saksi mata (Abdurrahman, 2007: 64).

\section{b) Wawancara (Interview)}

Dalam penelitian ini wawancara yang digunakan adalah wawancara semi berstruktur. Jenis wawancara ini sudah termasuk dalam katagori in-depth interview, dimana dalam pelaksanaksanaannya lebih bebas bila dibandingkan dengan wawancara berstruktur.

\section{c) Observasi}

Observasi adalah pengamatan suatu objek yang diteliti baik secara langsung maupun tidak langsung untuk memperoleh data yang harus dikumpulkan dalam penelitian. Menurut Moleong (2009: 9) Observasi adalah pengamatan atau pencacatan yang sisitematis.

\section{d) Dokumentasi}

Dokumen adalah setiap bahan tertulis ataupun film, lain dari record, yang tidak dipersiapkan karena adanya permintaan seorang penyelidik. Dokumen sering digunakan oleh peneliti sebagai sumber data karena dalam banyak hal dokumen sebagai sumber data dimanfaatkan untuk menguji, menafsirkan, bahkan untuk meramalkan. Jadi dokumen dalam penelitian ini digunakan sebagai pelengkap dari metode wawancara (Moleong, 2007: 217).

Supaya hasil dokumentasi dapat terekam dengan baik, dan peneliti memiliki bukti telah melakukan dokumentasi kepada informan atau sumber data, maka diperlukan bantuan alat-alat seperti yang sudah dijelaskan pada metode wawancara.

1) Buku catatan: berfungsi untuk mencatat semua percakapan dengan sember data. Sekarang sudah banyak komputer yang kecil, notebookyang dapat digunakan untuk membantu mencatat data hasil dokumentasi.

2) Tipe recorder: berfungsi untuk merekam semua percakapan atau pembicaraan. Penggunaan tape recorder dalam dokumentasi perlu memberitahu kenapa informan apakah dibolehkan atau tidak.

3) Camera: untuk memotret kalau peneliti sedang melakukan pembicaraan dengan informan/sumber data. Dengan adanya foto ini, maka dapat meningkatkan keabsahan peneliti akan lebih terjamin, karena peneliti benar-benar melakukan pengumpulan data.

Alat yang digunakan sesuai yang dipaparkan diatas, akan peneliti gunakan sebagai bahan atau data dokumentasi yang akan dijadikan sebagai hasil akhir atau kesimpulan dalam penelitian ini (Sugiyono, 2009: 308).

\section{Kritik}

Setelah sumber sejarah dalam berbagai kategorinya itu berkumpul, tahap berikutnya adalah vertivikasi atau kritik untuk memperoleh keabsahan sumber. Dalam hal ini, dilakukan uji keabsahan tentang keaslian sumber (autentisitas) yang dilakukan 
melalui kritik ekstern dan kebebasan tentang kesahihan sumber (kredibiliras) yang ditelusuri melalui kritik intern.

\section{Interpretasi}

Menurut Moleong (2007 : 151) menyatakan bahwa "Interpretasi data merupakan upaya untuk memperoleh arti dan makna yang lebih mendalam $\mathrm{dn}$ luas terhadap hasil penelitian yang sedang dilakukan.

Pembahasan hasil penelitian dilakukan dengan cara meninjau hasil penelitian secara kritis dengan teori yang relevan dan informasi yang akurat yang diperoleh dari lapangan".

Interprestasi sejarah sering disebut juga analisis sejarah, dalam hal ini ada dua metode yang digunakan yaitu analisis dan sintesis. Analisis berarti menguraikan dan sintesis berarti menyatakan. Keduanya dipandang sebagai metode utama didalam interprestasi analisis sejarah itu sendiri bertujuan melakukan sintesis atas sejumlah fakta yang di peroleh dari sumber-sumber sejarah dan bersama-sama dengan teori-teori disusunlah fakta itu dalam suatu interprestasi yang menyeluruh (Abdurrahman, 2007: 73).

\section{Historiografi}

Dalam penelitian tentang kehidupan sosial, ekonomi dan Budaya masyarakat Desa Labuhan Haji pasca G 30 September 1965-1970 ini maka metode yang digunakan adalah metode sejarah.

Fase terakhir dalam metode sejarah adalah historiografi merupakan suatu cara penulisan, pemaparan atau pelaporan hasil penelitian sejarah yang dilakukan.penulisan hasil penelitian ini diharapkan nantinya dapat memberikan gambaran yang jelas tentang proses panelitian dari awal sampai dengan akhir atau penarikan kesimpulan.

\section{Analisis Data}

Setelah data terkumpul, langkah selanjutnya adalah melakukan analisis.Data yang valid dan reliabel diperoleh peneliti dari hasil pengumpulan data yang valid dan reliabel pula.Untuk keperluan analisis data yang baik, selayaknya peneliti memperhatikan dan mempertimbangkan secara matang mengenai jenis data yang dipergunakan oleh peneliti (Asmani, 2011: 125-
126).

Analisis data dalam penelitian kualitatif, dilakukan pada saat pengumpulan data berlangsung, dan setelah selesai pengumpulan data dalam periode tertentu. Analisis data dalam penelitian kualitatif, yaitu:

a. Reduksi Data

Yaitu merangkum, memilih hal-hal yang pokok, memfokuskan pada ha-hal yang penting, mencari tema dan polanya.

b. Display Data

Setelah melakukan reduksi data, peneliti akan melakukan penyajian data dalam bentuk uraian, sehingga data yang terkumpul dapat memberi gambaran secara menyeluruh tentang apa yang sudah diteliti.

\section{c. Verifikasi Data}

Setelah melakukan reduksi dan display data (penyajian data) selanjutnya adalah menarik kesimpulan berdasarkan hasil penelitian yang dilakukan.

\section{HASIL DAN PEMBAHASAN}

Kehidupan sosial, ekonomi dan budaya masyarakat Desa Labuhan Haji pasca G 30 September tahun 19651970

Terjadinya peristiwa G 30 September merupakan kejadian yang menyakitkan bagi para pengusaha Cina maupun masyarakat Desa Labuhan Haji dan sekitarnya. Para pengusaha Cina terpaksa meninggalkan seluruh harta bendanya termasuk asetaset berupa pabrik yang telah mereka dirikan, begitu juga masyarakat Labuhan Haji dan sekitarnya, terjadinya peristiwa G 30 September menjadikan mereka kehilangan pekerjaan yang mengakibatkan kesulitan ekonomi. Padahal sebelum peristiwa G 30 September atau sebelum para pengusaha Cina diusir dari Labuhan Haji kesulitan ekonomi telah lama dialami masyarakat, kemudian ditambah lagi dengan akibat yang ditimbulkan oleh pristiwa tersebut. Akan tetapi yang menjadi permasalahan adalah apakah benar minoritas Etnis Cina di Labuhan Haji adalah komunis ataukah mereka hanya terkena pitnah pihak-pihak yang tidak bertanggung jawab.

Akibat dari peristiwa tersebut perekonomian 
masyarakat Labuhan Haji mengalami penurunan. Sehingga banyak masyarakat Labuhan Haji yang kembali menjadi nelayan dan petani karena pabrik-pabrik dan toko-toko yang dibangun oleh orang Cina dibakar oleh masyarakat. Menurut keterangan Amaq Maksum (80 tahun), mengatakan bahwa:

"Pada saat terjadinya pengganyangan Etnis Cina di Desa Labuhan Haji tahun 1965, semua pabrikpabrik dan toko-toko yang di bangun oleh Etnis Cina dibakar oleh masyarakat".(wawancara $15 / 11 / 2016)$

Dengan sangat terpaksa maka para pengusaha Cina yang berada di Labuhan Haji meninggalkan harta benda yang mereka miliki, untuk menyelamatkan diri dari amukan masa. Peristiwa tersebut merupakan dampak dari peristiwa G 30 September yang ada di Jakarta. Masyarakat pada saat itu tergolong masyarakat awam mencurigai setiap orang asing atau bangsa pendatang kecuali para pedagang dari Etnis Arab, karena mereka menganggap seagama. Akhirnya pada awal bulan Oktober 1965 maka Etnis Cina yang ada di Labuhan Haji dipaksa meninggalkan tempat tinggal dan harta benda mereka. Masyarakat yang tergolong dalam ikatan atau kelompok yang menamakan diri kaum Ansor memporak-porandakan pemukiman para pengusaha Cina yang disebut oleh masyarakat sampai sekarang dengan istilah "Ganyangan Cina". Seluruh harta benda yang ditinggalkan oleh para pengusaha Cina diambil oleh masyarakat Desa Labuhan Haji.

Kondisi prekonomian masyarakat di Lombok Timur benar-benar memprihatinkan. Bahkan seperti beras, minyak tanah, sandang dan lain-lainya sangat terbatas di pasaran, kalaupun ada harganya jauh dari jangkauan dan daya beli masyarakat. Akibatnya pembeli dengan jatah kupon dan antri merupakan pemandangan sehari-hari, kemiskinan dan kelaparan adalah kehidupan yang dijalani masyarakat Lombok Timur.

Kondisi sosial ekonomi dan bidang-bidang lain seperti prasarana dan sarana bangunan umum hampir tidak sempat direhabilitasi karena pendapatan masyarakat yang rendah disebabkan oleh inflasi. Begitu juga di daerah Labuhan Haji dan sekitarnya, kesulitan ekonomi yang melanda rakyat menimbulkan berbagai ketegangan di tengah masyarakat terutama peristiwa terusirnya para pengusaha Cina di Daerah Labuhan Haji. Menurut keterangan Amaq Maksum (80 tahun), mengatakan bahwa:

"Setelah diusirnya Etnis Cina di Desa Labuhan Haji prekonomian kami semakin menurun, dulu saya bekerja di pabrik penggilingan padi milik pengusaha Cina namun setelah terjadinya peristiwa G 30 september saya kembali bekerja sebagai nelayan yang penghasilannya lebih sedikit jika dibanding bekerja di pabrik milik pengusaha Cina".(wawancara 15/11/2016)

Di tengah kesulitan ekonomi yang dihadapi masyarakat Labuhan Haji dan sekitarnya pada waktu itu ternyata terjadi juga persaingan dagang atau persaingan usaha antara para pengusaha Cina dan Arab hal ini tidak menutup kemungkinan mengakibatkan Etnis Cina di Labuhan Haji terpaksa meninggalkan Labuhan Haji. Sebab apabila dikatakan bahwa Etnis Cina yang ada di Labuhan Haji adalah PKI tapi tidak ada bukti yang menguatkan karena pada saat itu partai yang berkembang di daerah itu adalah NU dan Masumi. Karena di Tiongkok berkembang partai komunis maka Etnis Cina yang ada di Labuhan Haji dianggap sebagai anggota partai komunis mengingat bahwa di Jakarta berkembang partai komunis yang didukung kuat oleh Ir. Soekarno. Apalagi diterapkannya ketentuan Nasakomisasi yang dianggap merongrong kewibawaan islam dan tidak diterima oleh masyarakat Indonesia khususnya masyarakat Lombok Timur Nusa Tenggara Barat.

Desa Labuhan Haji adalah salah satu desa dari delapan desa yang berada di wilayah administratif Kecamatan Labuhan Haji. Berdasarkan sejarah, daerah ini dinamakan Labuhan Haji karena pada era pendudukan Belanda dan Jepang masyarakat Lombok memanfaatkan pelabuhan ini sebagai tempat awal berangkat menunaikan ibadah haji ke Mekah, Arab Saudi.

Pada tahun 1895, alat transportasi belum secanggih sekarang, dan masih didominasi melalui perairan laut menggunakan kapal layar untuk sampai di tanah suci, calon-calon haji ini berjuang di laut dan setidaknya membutuhkan tiga bulan perjalanan dalam sekali kesempatan pergi haji. Disamping penggunaannya sebagai pelabuhan untuk pergi berhaji, tempat ini 
berfungsi pula sebagai pintu masuk para pedagang keturunan Cina ke wilayah Lombok. Usaha mereka tergolong sukses karena dominasi ekonomi pengusaha Cina sangat menonjol, yaitu sebagian besar pemilik pabrik penggilingan padi dan minyak kelapa adalah golongan Etnis Cina. Beberapa lokasi kuburan warga keturunan Cina juga dapat ditemukan seperti terlihat pada daerah Penede Gandor, sekitar 500 meter dari pelabuhan.

Pengusaha Cina membangun pabrik-pabrik di Desa Labuhan Haji, dengan adanya pabrik-pabrik ini otomatis memberikan peluang usaha terhadap perekonomian masyarakat Labuhan Haji dan sekitarnya, khususnya masyarakat Labuhan Haji yang sebagian besar berprofesi sebagai nelayan dan ada juga yang sebagai petani ini merupakan budaya yang sudah turun temurun dari nenek moyang sebelumnya, secara otomatis kehidupan masyarakat Desa Labuhan Haji mengalami perubahan dalam bidang prekonomian.

Masyarakat Labuhan Haji menjual hasil penangkapan dan hasil pertaniannya pada pengusaha Cina dan tidak sedikit pula masyarakat yang bekerja sebagai kuli di pabrik-pabrik tertentu. Tidak hanya itu, dengan keberadaan pengusaha Cina ini berarti membuka lowongan kerja di bidang transportasi yaitu bongkar muat barang di pelabuhan Labuhan Haji maupun jalan darat. Dengan demikian selain bekerja sebagai kuli pabrik, dan sebagai produsen barang mentah untuk pabrik pengusaha Cina berarti masyarakat Desa Labuhan Haji Kecamatan Labuhan Haji juga dapat bekerja sebagai kuli bongkar muat barang baik di pelabuhan maupun di darat.

Kegiatan prekonomian yang dilakukan bangsa Cina dan perkembangannya cukup pesat di Desa Labuhan Haji ternyata tidak berlangsung lama. Hal ini disebabkan karena diusirnya para pengusaha Cina oleh bangsa pribumi dari daerah Labuhan Haji, pristiwa inilah yang sampai saat ini disebut oleh masyarakat sebagai pristiwa “Pengganyangan Cina” pada tahun 1965, dimana seluruh harta benda seperti rumah, pabrik barang dagangan dan barang-barang berharga lainnya yang menjadi milik para pengusaha Cina habis dijarah oleh bangsa pribumi. Hal ini disebabkan karena Etnis Cina di Labuhan Haji dianggap sebagai antek PKI. Operasi pengejaran terhadap pimimpinan dan pendukung PKI segera dilakukan.

Masyarakat Indonesia beraksi dengan menuntut pembubaran PKI. Sejak akhir Oktober 1965 kesatuan aksi dibentuk oleh mahasiswa dan kelompok lainnya. Semua kesatuan aksi menyerukan pembubaran PKI, seruan untuk memberantas PKI dan Antekanteknya menyebar keseluruh wilayah Indonesia.

Dalam kehidupan bermasyarakat tentu akan terjadi hubungan atau interaksi antara manusia yang satu dengan yang lainnya atau individu yang satu dengan individu yang lainnya untuk memenuhi kebutuhan hidupnya baik itu kebutuhan hidup yang abstrak atau jasa maupun barang seperti sandang papan dan pangan. Pada tahun 1960-an antara masyarakat Labuhan Haji dengan para pengusaha Cina terjadi hubungan sosial yang cukup baik, yaitu hubungan antara penduduk asli dengan pendatang. Ada juga sebagian dari pengusaha Cina melakukan perkawinan dengan masyarakat Labuhan Haji hingga mereka memiliki keturunan. Adanya masyarakat keturunan Cina di Desa Labuhan Haji menandakan bahwa masyarakat dan pemerintah Desa Labuhan Haji menjalin hubungan yang cukup baik dengan bangsa Cina yang berdomisili di Desa Labuhan Haji itu sendiri sekitar tahun 1960.

\section{SIMPULAN DAN SARAN}

\section{Kesimpulan}

Adapun kesimpulan yang penulis peroleh dari hasil analisa penelitian meliputi.

a) Peristiwa G 30 September berdampak terhadap kehidupan sosial, ekonomi dan budaya masyarakat Desa Labuhan Haji.

b) Sebelum G 30 september tahun 1960-1965, Pengusaha Cina membangun pabrik-pabrik di Desa Labuhan Haji dengan adanya pabrik tersebut otomatis memberikan peluang usaha terhadap prekonomian masyarakat Desa Labuhan Haji karena masyarakat Labuhan Haji dapat bekerja di pabrik tersebut. Hubungan sosial budaya masyarakat Labuhan Haji dengan Etnis Cina terjalin dengan baik meskipun berbeda suku, ras dan adat 
istiadat.

c) Terjadinya G 30 September tahun 1965 menyebabkan diusirnya Etnis Cina dari Desa Labuhan Haji karena dianggap sebagai antek-antek PKI, padahal belum terbukti kebenarannya mereka hanya terkena fitnah dari orang- orang yang tidak bertanggung jawab. Diusirnya Etnis Cina dari Desa Labuhan Haji mengakibatkan hubungan sosial, ekonomi dan budaya masyarakat Labuhan Haji menurun.

\section{2 .Saran}

a) Bagi Pemerintah

Menjadi pandangan pemerintah agar lebih meningkatkan stabilitas politik yang berkaitan erat dengan kehidupan sosial, ekonomi dan budaya masyarakat.

b) Bagi Masyarakat

Sebagai bahan pemikiran atau pertimbangan bagi masyarakat untuk berfikir lebih positif sebelum melakukan suatu tindakan anarkis agar peristiwa kekerasan tahun 1965 yang pernah terjadi di Labuhan Haji tidak terulang lagi.

c) Bagi Peneliti Selanjutnya

Penelitian ini dapat dijadikan motivasi dan referensi untuk melakukan penelitian selanjutnya yang lebih komprehensif.

Hasil penelitian ini diharapkan dapat mengembangkan pemikiran- pemikiran yang baru bagi para peneliti dalam rangka meningkatkan mutu pendidikan yang lebih baik.

\section{DAFTAR RUJUKAN}

Abdullah, Taufik. (1990). Sejarah Lokal di Indonesia. Yogyakarta : Gadjah Mada University Press.

Abdurrahman, Dudung. 2007.Metodelogi Penelitian Sejarah. Jogjakarta:Ar-Ruzz Media

Arikunto, Suharsimi. 2006. Prosedur Penelitian Suatu Pendekatan Praktis. Jakarta: Rineka Cipta

Asmani, Jamal Ma'mur. 2011. Tuntunan Lengkap Metodologi Praktis: Penelitian Pendidikan. Yogyakarta: Diva Press

Baharuddin. 2010. Sosiologi suatu pengantar. Yogyakarta: Kurnia Kalam Smesta
Bugin, Burhan. 2007. Penelitian Kualitatif. Jakarta : Kencana Damsar. 2002. Sosiologi Ekonomi. Jakarta : PT. Grafindo Persada

Estan, Mursal.1999.Kajian Transformasi Budaya. Bandung: Angkasa Bandung.

Kartodirdjo Sartono. 1992. Pendekatan Ilmu Sosial Dalam Metodologi Sejarah. Jakarta : Gramedia

Koentjaraningrat. 2009. Pengantar Ilmu Antropologi. Jakarta: PT. Rineka Cipta

Koentjaraningrat. 2005. Metode-Metode Penelitian Masyarakat. Jakarta : PT. Gramedia

Koentjaraningrat. 2010. Pengantar Ilmu Antropologi. Jakarta : PT. Rineka Cipta.

Kuntowijoyo. 2003. Metodologi Sejarah. Yogyakarta : Tina Wacana Jogja. Mariyani. 2005. Metodologi Kebudayaan. Jakarta : PT. Bumi Aksara

Margono. 1996. Metode Penelitian Pendidikan. Jakarta: Rineka Cipta

Moleong Lexy. J. 2007. Metodologi Penelitian Kualiatitatif. Bandung : PT. Remaja Rosdakarya.

Supardan, Dadang. (2000). "Kreativitas guru Sejarah dalam Pembelajaran Sejarah (Studi Deskriptif-Analitis terhadap guru dan Implementasinya untuk pogram pengembangan kreativitas guru sejarah Sekolah Menengah Umum di Kabupaten Bandung)". Tesis pada Sps. UPI Bandung: tidak diterbitkan

Tilaar, H.A.R (2007). Mengindonesia Etnisitas dan Identitas Bangsa Indonesia: Tinjauan dari Perspektif Ilmu Pendidikan. Jakarta: PT. Rhineka Cipta. 